\title{
Effect of Price and Promotion on Customer Loyalty of Domestic and Export Coal in the Time of the COVID-19 Pandemic
}

\author{
Muhammad Firdaus \\ Master of Management, Sriwijaya University, Palembang, Indonesia \\ Corresponding author email: m01firdaus09@gmail.com \\ Zakaria Wahab \\ Lecturer of Master Management, Economic Faculty, Sriwijaya University, Palembang, Indonesia \\ Email: zkwahab01@gmail.com \\ Marlina Widiyanti \\ Lecturer of Magister Management, Economic Faculty, Sriwijaya University, Palembang, Indonesia \\ Email: marlinawidiyanti68@yahoo.co.id \\ Muchsin Saggaf Shihab \\ Lecturer of Magister Management, Economic Faculty, Sriwijaya University, Palembang, Indonesia \\ Email: muchsin.shihab@bakrie.ac.id
}

\begin{abstract}
This study was conducted to determine the effect of price and promotion on the loyalty of domestic and export coal customers during the COVID 19 pandemic at PT Bukit Asam, Tbk. The population in this study were all domestic and export coal consumers who made purchases during the COVID-19 pandemic at PT. Bukit Asam, Tbk in 2020 as many as 58 companies. Determining the sample in this study uses a purposive sampling technique. With consideration to save time and effort and get more accurate results, the number of samples used in this study was 100 respondents distributed through distributing questionnaires. The multiple linear regression analysis results show that price has a positive and significant effect on customer loyalty for domestic and export coal during the COVID19 pandemic at PT Bukit Asam, Tbk. Sales promotion positively and significantly affected customer loyalty for domestic and export coal during the COVID 19 pandemic at PT Bukit Asam, Tbk. The price variable is expected to make adjustments in determining the price of coal by surveying competitors who sell coal. In the sales promotion variable, it is expected that the company can improve in doing more attractive advertising.

Keywords---COVID-19 pandemic, customer loyalty, domestic and export, price, promotion.
\end{abstract}

\section{Introduction}

In an era of increasingly competitive competition, every company is increasingly aware of the importance of the customer loyalty aspect to ensure the continuity of their business (Rauyruen \& Miller, 2007). A loyal customer becomes a precious asset for the company. Maintaining loyal customers can reduce the effort to find new customers, which means giving positive feedback to the company. Companies can make more cost savings by retaining old customers rather than looking for new ones (Kotler et al., 2019).

Loyalty is a behavioral manifestation of units to make a purchase decision continually against the goods on services of a company that is selected (Griffin, 2013). Consumer loyalty is a multidimensional concept which is a type of customer preference for products and services that are long-established related to cognitive, affective, and conative aspects of consumer behavior (Oliver, 1999). Loyal consumers remain committed to making purchases at 
the same brand, are willing to pay a higher price for a product or service brand, and consistently promote the brand (Natarajan et al., 2016).

The first factor that affects customer loyalty is price. Price is the amount of money charged for a product or service or the amount of value that customers exchange for the benefits of owning or using a product or service (Kotler \& Armstrong, 2015). The price solely depends on the company's policy but takes into account various things. The low or high price of a product is very relative. Companies must constantly monitor the prices set by competitors so that the prices set by the company are not too high or vice versa. A pricing strategy is essential to attract consumers' attention (Ngo et al., 2016; Poncet \& De Waldemar, 2013). The right price is a price that follows the quality of the product or service offered, and that price can provide a purchasing decision. Marketers seek to achieve specific goals through the components of pricing. Some companies try to increase profits by setting low prices to attract new business (Gie, 2020).

The second factor that influences customer loyalty is promotion. Promotion (promotion) is an activity undertaken by the company to communicate the benefits of their products and convince consumers to buy (Lin \& Wang, 2006; Bobâlcă et al., 2012). Sales promotion is a variety of short-term incentives to encourage the purchase or sale of products or services (Kotler \& Armstrong, 2015). A good promotion will benefit producers, where the promotion will generate goodwill for the brand so that businesses with considerable goodwill will find it easier to obtain capital (Mangold \& Faulds, 2009; Frondel et al., 2010).

Table 1

Coal Price List PT. Bukit Asam, Tbk 2016-2020

\begin{tabular}{lccccc}
\hline \multirow{2}{*}{ Description } & \multicolumn{5}{c}{ Coal Price (USD/Ton) } \\
\cline { 2 - 6 } & 2020 & 2019 & 2018 & 2017 & 2016 \\
\hline HBA (6322 GAR) & 58,212 & 77.893 & 98,964 & 85.918 & 61.835 \\
Newcastle Index (6322 & 60,447 & 77.772 & 107.340 & 88,464 & 66.112 \\
GAR) & & & & & \\
ICI-3 (5000 GAR) & 43.114 & 50,390 & 60,747 & 61,595 & 46.518 \\
\hline
\end{tabular}

Source: Internal Data of PT. Bukit Asam, Tbk

The data in Table 1 shows price fluctuations for this type of coal. The HBA coal type (6322 GAR) showed the highest price in 2018 at $\$ 98,964$ per tonne, while the lowest price for HBA coal (6322 GAR) occurred in 2020 at $\$ 58,212$ per tonne. Meanwhile, the Newcastle Index (6322 GAR) coal showed that the highest price occurred in 2018 at $\$ 107,340$ per tonne, and the lowest price occurred in 2020 at $\$ 60,447$ per tonne. In ICI-3 (5000 GAR) coal type, the highest price occurred in 2017 at $\$ 61,595$ per tonne, and the lowest price occurred in 2020 at $\$ 43,114$ per tonne.

Table 2

Coal Sales PT. Bukit Asam, Tbk 2016-2020

\begin{tabular}{lccccc}
\hline \multirow{2}{*}{ Description } & \multicolumn{5}{c}{ Sales Tonnage/ Ton } \\
\cline { 2 - 6 } & 2020 & 2019 & 2018 & 2017 & 2016 \\
\hline Domestic & $14,135,858$ & $16,677,939$ & $13,910,463$ & $14,386,772$ & $12,267,467$ \\
Export & $11,989,018$ & $11,115,462$ & $10,782,399$ & $9,241,103$ & $8,485,700$ \\
Total & $26,124,876$ & $27,793,401$ & $24,692,862$ & $23,627,875$ & $20,753,167$ \\
\hline
\end{tabular}

Source: Internal Data of PT. Bukit Asam, Tbk

The data in Table 1.2, it can be seen that coal sales of PT. Bukit Asam, Tbk experienced fluctuations. The highest domestic sales category occurred in 2019 at 16,677,939 per tonne, while the lowest sales in the domestic sales category occurred in 2016 at 12,267,467 per tonne meanwhile, coal sales of PT. Bukit Asam, Tbk in the highest export sales category occurred in 2020 at 11,989,018 per tonne, while the lowest sales in the export sales category occurred in 2016 at $8,485,700$ per ton. 
Table 3

Coal Revenue PT. Bukit Asam, Tbk 2016-2020

\begin{tabular}{lccccc}
\hline \multirow{2}{*}{ Description } & \multicolumn{5}{c}{ Income (Million Rupiah) } \\
\cline { 2 - 6 } & 2020 & 2019 & 2018 & 2017 & 2016 \\
\hline Domestic & $9,587,277$ & $12,888,125$ & $10,970,781$ & $12,163,084$ & $8,223,851$ \\
Export & $7,737,915$ & $8,889,439$ & $10,196,212$ & $7,307,946$ & $5,835,018$ \\
$\quad$ Total & $17,325,192$ & $21,166,993$ & $21,166,993$ & $19,471,030$ & $14,058,869$ \\
\hline
\end{tabular}

Source: Internal Data of PT. Bukit Asam, Tbk

The data in Table 2 shows the revenue from coal sales of PT. Bukit Asam, Tbk in 2016-2020 experienced fluctuations. The domestic category revenue from coal sales showed the highest revenue occurred in 2019 at $12,888,125$ (million Rupiah), while the lowest coal sales revenue in the domestic category occurred in 2016 at $8,223,851$ (million Rupiah). In the export category, revenue from coal sales showed the highest revenue occurred in 2018, amounting to 10,196.212 (million Rupiah), while the lowest income from sales in the export category occurred in 2016 5,835.018 (million Rupiah).

Based on these data, the business phenomenon due to price fluctuations, especially in 2020, shows the lowest coal price compared to previous years. The revenue and sales data above also show fluctuations, as indicated by the export category, is still-low sales and income. So based on the attached data, the author is interested in continuing research on prices and promotions of customer loyalty for domestic and export coal during the COVID-19 pandemic (Chen et al., 2006), which shows a decline in prices and income due to lack of promotions to provide a sense of customer loyalty (Kumar \& Shah, 2004). Thus, this study aims to examine further the effect of price and sales promotion on customer loyalty for domestic and export coal during the COVID-19 pandemic at PT. Bukit Asam, Tbk.

\section{Research Methods}

The population in this study were all domestic and export coal consumers who made purchases during the COVID19 pandemic at PT. Bukit Asam, Tbk in 2020 as many as 58 companies. The sample size is determined from the sample size, which is greater than 30 respondents and less than 500 respondents (Rescoe, 2006). The technique of determining the sample in this research uses the purposive sampling technique. With consideration to save time, effort and get more accurate results, the number of samples used in this study was 100 respondents who were distributed through distributing questionnaires to all domestic and export coal consumers who made purchases during the COVID-19 pandemic at PT. Bukit Asam, Tbk in 2020.

\section{Results and Discussion}

Multiple linear regression analysis results

$$
Y=0,105+0,671 X_{1}+0,192 X_{2}+e
$$

The linear regression equation above can be explained as follows:

a) The constant value shows a positive value with a value of 0.105 . This shows that customer loyalty is considered that without the influence of price and sales promotion, the magnitude of the customer loyalty variable is 0.105 .

b) The regression coefficient value of the price variable is 0.671 with a value $t_{\text {count }}$ of 8.563 , which states that price positively affects customer loyalty. This shows that the higher the price, the positive impact will be, namely, the higher the loyalty of domestic and export coal customers during the COVID 19 pandemic at PT Bukit Asam, Tbk.

c) The regression coefficient value of the brand sales promotion variable is 0.192 with a value $t_{\text {count }}$ of 2.455 , stating that sales promotion positively affects customer loyalty. This shows that the higher the sales promotion, the higher the loyalty of domestic and export coal customers during the COVID 19 pandemic at PT Bukit Asam, Tbk. 
Result of Correlation Coefficient ( $r)$ and Coefficient of Determination $\left(R^{2}\right)$

Based on the output model summary, the results of the correlation coefficient test (r) show that the magnitude of the influence of price and sales promotion variables on customer loyalty is 0.810 or $81.0 \%$. The $R$ square $\left(\mathrm{R}^{2}\right)$ is 0.657 or $65.7 \%$; this figure is used to see how prices and sales promotions affect the loyalty of domestic and export coal customers during the COVID 19 pandemic at PT Bukit Asam Tbk. This figure means how the price and sales promotion variables show what factors can affect customer loyalty, and together it is $65.7 \%$ while the remaining $34.3 \%$ is influenced by other factors such as service quality, product quality, promotion (Marshall et al., 2013; Marto et al., 1986).

\section{Model Conformity Results (Test F)}

Based on the results of the model suitability test (Test F), obtained a significance value of 0.000 because the significance value is $0.000<0.05$, it can be said that the linear regression model obtained is feasible to be used to explain the effect of price and sales promotion on customer loyalty.

\section{Individual Parameter Significance Test Results (t-Test)}

Based on the individual parameter significance test (t-test), the value of the degree of freedom $(\mathrm{df})=\mathrm{NK}=100-3=$ 97 and 0.05 , the value $t_{\text {table }}$ for this research data is 1.984 . The results of the analysis can be explained as follows:

a) Value $t_{\text {count }}$ rice variable (X 1 ) 8.563 and the significant value of 0.000 , the value $t_{\text {count }}>t_{\text {table }}(8.563>$ 1.984) or value (Sig.) $0.000<0.05$. This means that the price significantly affects coal customer loyalty at PT Bukit Asam, Tbk. This proves that the first hypothesis on the price variable has a positive and significant effect and can be accepted.

b) The value of $t_{\text {count }}$ the sales promotion variable (X 2 ) is 2.455 and the significance value is 0.016 , so the value $t_{\text {count }}>t_{\text {table }}$ is $(2.455>1.984)$ or the value $(\mathrm{Sig}$.) is $0.016<0.05$. This means that sales promotions significantly affect coal customer loyalty at PT Bukit Asam, Tbk. This proves that the second hypothesis on the sales promotion variable has a positive and significant effect and can be accepted.

Price is the amount of money charged for a product or service, or the sum of the value of the exchanged customers to benefit from owning or using a product or service (Kotler \& Armstrong, 2015). Price is an important factor for consumers as a consumer consideration in consuming a product or service because, for customers, the price is often used as an indicator of value when the price is associated with the perceived benefits of the goods/services consumed. Customers feel that they match the price paid for the goods they buy, then customers will automatically be loyal to repurchase at that place (Kotler \& Armstrong, 2015).

Price has a positive and significant effect on customer loyalty. These results are in line with research results from (Xie, 2020), (Anggraini \& Budiarti, 2020), (Cardia et al., 2019), (Sudaria et al., 2019), (Othmana et al., 2019), (Wijaya, 2018), (Salim \& Hermani, 2018), (Maslakhah \& Andjarwati, 2018), (Mursyid, 2018), (Pangaila et al., 2018), (Dewi \& Suprapti, 2018), (Putra \& Ekawati, 2017), (Olotewo, 2017), (Anggraini \& Suryoko, 2018), (Putra \& Suryoko, 2017), (Rotinsulu et al., 2015), (Maulana et al., 2016), show the results that price has a positive and significant effect on customer loyalty.

This study indicates that prices are associated with several indicators such as affordability, price conformity with product quality, price competitiveness, price suitability with benefits. In the coal price indicator produced by PT Bukit Asam, Tbk can compete with coal from other companies showing the lowest value. It is suspected that the price of coal produced by PT Bukit Asam, Tbk provides a higher price when compared to other coal competitors. PT Bukit Asam, Tbk, the affordable coal price indicator, shows the highest score. This shows that the price of coal produced by PT Bukit Asam, Tbk provides a price that follows the quality of the product produced (Turgunovna, 2021).

Promotion (promotion) is an activity undertaken by the company to communicate the benefits of their products and convince consumers to buy. Sales promotion is a variety of short-term incentives to encourage the purchase or sale of a product or service (Kotler \& Armstrong, 2015). A good promotion will provide benefits to producers, where the promotion will create goodwill for the brand so that businesses with considerable goodwill will find it easier to obtain capital. In addition, promotions can not only cause an increase in product sales, but can cause stability in production; another effect of promotion is that producers will avoid competition based on price, wherewith 
promotions consumers make purchases not based on price alone, but Another factor is consumer interest in the brand, which means that consumers will be loyal to a product (Usmanova \& Mirkhamidova, 2021).

Sales promotion has a positive and significant effect on customer loyalty. These results are in line with research results from (Xie, 2020), (Oyeniyi, 2011), (Katole, 2020), (Saeed et al., 2020), (Pratama \& Pradekso, 2020), (Sudaria et al., 2019), (Bui \& Muñoz Martinez, 2019), (Urun, 2019), (Cardia et al., 2019), (Othmana et al., 2019), (Sari et al., 2018), (Zalova \& Karaduman, 2018), (Onikola \& Adedokun, 2018), (Mendez, 2018), (Pembi et al., 2017), (Olotewo, 2017), (Rotinsulu et al., 2015), shows that sales promotion has a positive and significant effect on customer loyalty.

The results showed that promotion is associated with several indicators such as advertising (advertising), sales promotion (sales promotion), personal selling (personal selling), public relations (public relations), and direct sales (direct marketing). The advertising indicators displayed by PT Bukit Asam, Tbk are attractive and easy to find, showing the lowest values. It is suspected that the display of advertisements for PT Bukit Asam, Tbk's coal is still challenging to find in public places, especially in the introduction of products and types of coal. In the indicator, PT Bukit Asam, Tbk is often a sponsor in several activities or events showing the highest value. This shows that PT Bukit Asam, Tbk is often a sponsor in several activities, making PT Bukit Asam increasingly known by the wider community.

\section{Conclusion}

Prices and promotions positively impact customer loyalty for domestic and export coal during the COVID-19 pandemic at PT Bukit Asam, Tbk.

\section{Acknowledgments}

The author expresses his deep gratitude to the academic parties who have provided support in the form of feedback.

\section{References}

Anggraini, F., \& Budiarti, A. (2020). Pengaruh Harga, Promosi, Dan Kualitas Pelayanan Terhadap Loyalitas Pelanggan Dimediasi Kepuasan Pelanggan Pada Konsumen Gojek. Jurnal Pendidikan Ekonomi (JUPE), 8(3), 86-94.

Anggraini, N. P., \& Suryoko, S. (2018). Pengaruh Labelisasi Halal, Harga Dan Kualitas Produk Terhadap Loyalitas Pelanggan Melalui Kepusan Pelanggan (Studi Pada Konsumen Kosmetik Sariayu Di Kota Semarang). Jurnal Ilmu Administrasi Bisnis, 7(3), 359-369.

Bobâlcă, C., Gătej, C., \& Ciobanu, O. (2012). Developing a scale to measure customer loyalty. Procedia Economics and Finance, 3, 623-628. https://doi.org/10.1016/S2212-5671(12)00205-5

Bui, A. Q., \& Muñoz Martinez, V. (2019). The impact of product promotion on customer loyalty: A quantitative study on Zara.

Cardia, D.I.N.R., Santika, I.W., \& Respati, N.N.R. (2019). Pengaruh Kualitas Produk, Harga dan Promosi Terhadap Loyalitas Pelanggan. E-J. Manaj. 8, 6762-6781.

Chen, C. H., Mai, C. C., \& Yu, H. C. (2006). The effect of export tax rebates on export performance: Theory and evidence from China. China Economic Review, 17(2), 226-235. https://doi.org/10.1016/j.chieco.2005.06.001

Dewi, P. S. A., \& Suprapti, N. W. S. (2018). Membangun Loyalitas Pelanggan melalui Kepuasan yang Dipengaruhi oleh Kualitas Produk, Persepsi Harga, dan Citra Merek. Matrik: Jurnal Manajemen, Strategi Bisnis, dan Kewirausahaan, 12(2), 87-98.

Frondel, M., Ritter, N., Schmidt, C. M., \& Vance, C. (2010). Economic impacts from the promotion of renewable energy technologies: The German experience. Energy Policy, 38(8), 4048-4056. https://doi.org/10.1016/j.enpol.2010.03.029

Gie, 2020. Strategi Penetapan Harga: Cara, Metode, Dan Fungsinya [WWW Document].

Griffin, G. (2013). Britain and the European Union. Edinburgh University Press.

Katole, H. (2020). Effect of sales promotion campaign adopted by retailer India. Journal of Critical Reviews, 7(2), 583-586.

Kotler, P., \& Armstrong, G. (2015). Marketing an Intoducing Prentice Hall, 12th ed. Pearson Education, Inc, England.

Kotler, P., Kartajaya, H., \& Setiawan, I. (2019). Marketing 3.0: From products to customers to the human spirit, in: Marketing Wisdom. Springer, 139-156.

Kumar, V. I. S. W. A. N. A. T. H. A. N., \& Shah, D. (2004). Building and sustaining profitable customer loyalty for the 21st century. Journal of retailing, 80(4), 317-329. https://doi.org/10.1016/j.jretai.2004.10.007 
Lin, H. H., \& Wang, Y. S. (2006). An examination of the determinants of customer loyalty in mobile commerce contexts. Information \& management, 43(3), 271-282. https://doi.org/10.1016/j.im.2005.08.001

Mangold, W. G., \& Faulds, D. J. (2009). Social media: The new hybrid element of the promotion mix. Business horizons, 52(4), 357-365. https://doi.org/10.1016/j.bushor.2009.03.002

Marshall, M., Pronovost, P., \& Dixon-Woods, M. (2013). Promotion of improvement as a science. The Lancet, 381(9864), 419-421.

Marto, P. J., Looney, D. J., Rose, J. W., \& Wanniarachchi, A. S. (1986). Evaluation of organic coatings for the promotion of dropwise condensation of steam. International journal of heat and mass transfer, 29(8), 1109-1117. https://doi.org/10.1016/0017-9310(86)90142-0

Maslakhah, A. N., \& Andjarwati, A. L. (2018). Pengaruh Kualitas Produk Dan Promosi Penjualan Terhadap Keputusan Pembelian Mascara Oriflame (Studi Pada Konsumen Mascara Oriflame Wilayah Surabaya Pusat). Jurnal Ilmu Manajemen (JIM), 6(4).

Maulana, M. I., Suryoko, S., \& Prabawani, B. (2016). Pengaruh kualitas pelayanan dan harga terhadap loyalitas pelanggan melalui kepuasan pelanggan sebagai variabel intervening. Jurnal Ilmu Administrasi Bisnis, 5(1), 206216.

Mendez, M. (2018). Sales Promotions Effects on Customer Loyalty. Nova Southeast. Univ. NSU Fla. J.

Mursyid, G. M. (2018). Pengaruh Promosi, Kualitas Pelayanan dan Harga Terhadap Loyalitas Pelanggan (Studi Empiris pada Pelanggan Foto Studio 26 Surakarta)(Doctoral dissertation, Universitas Muhammadiyah Surakarta).

Natarajan, S., Kailath, B. J., Kumar, D., \& Kumar, R. (2016). Accelerating occupancy grid map computation with gpu for real-time obstacle detection. In 2016 22nd Annual International Conference on Advanced Computing and Communication (ADCOM) (pp. 38-43). IEEE.

Ngo, V. D., Janssen, F., Leonidou, L. C., \& Christodoulides, P. (2016). Domestic institutional attributes as drivers of export performance in an emerging and transition economy. Journal of Business Research, 69(8), 2911-2922. https://doi.org/10.1016/j.jbusres.2015.12.060

Oliver, R. L. (1999). Whence consumer loyalty?. Journal of marketing, 63(4_suppl1), 33-44.

Olotewo, J. (2017). Analysing the moderating effect of customer loyalty on long run repurchase intentions. African Journal of Marketing Management, 9(3), 25-34.

Onikola, Y., Adedokun, F. (2018). Sales Promotion Dimensions and Consumer Loyalty: An Empirical Investigation of Nigerian Manufacturing Companies in Oyo State. Int. J. Bus. Law Res. 6(3), 24-33.

Othman, B., Harun, A., Rashid, W., Nazeer, S., Kassim, A., \& Kadhim, K. (2019). The influences of service marketing mix on customer loyalty towards Umrah travel agents: Evidence from Malaysia. Management Science Letters, 9(6), 865-876.

Oyeniyi, O. (2011). Sales promotion and consumer loyalty: A study of nigerian tecommunication industry. Journal of Competitiveness|, 66-77.

Pangaila, P. A., Worang, F. G., \& Wenas, R. S. (2018). Pengaruh Kualitas Pelayanan dan Harga Terhadap Loyalitas Pelanggan Pengguna Aplikasi Gojek (Studi Pada Pengguna Layanan Go-Ride di Kota Manado). Jurnal EMBA: Jurnal Riset Ekonomi, Manajemen, Bisnis dan Akuntansi, 6(4).

Pembi, S., Fudamu, A. U., \& Adamu, I. (2017). Impact of sales promotional strategies on organizational performance in Nigeria. European Journal of Research and Reflection in Management Sciences Vol, 5(4).

Poncet, S., \& De Waldemar, F. S. (2013). Export upgrading and growth: the prerequisite of domestic embeddedness. World Development, 51, 104-118. https://doi.org/10.1016/j.worlddev.2013.05.010

Pratama, I. W., \& Pradekso, T. (2020). Pengaruh Terpaan Promosi Penjualan, Citra Merek dan Nilai Pelanggan terhadap Loyalitas Konsumen Aplikasi OVO di Semarang. Interaksi Online, 8(4), 83-93.

Putra, M. C. S. D., \& Ekawati, N. W. (2017). Pengaruh Inovasi Produk, Harga, Citra Merek Dan Kualitas Pelayanan Terhadap Loyalitas Pelanggan Sepeda Motor Vespa (Doctoral dissertation, Udayana University).

Putra, R., \& Suryoko, S. (2017). Pengaruh Harga Dan Kualitas Pelayanan Terhadap Loyalitas Pelanggan Dengan Kepuasan Pelanggan Sebagai Variabel Intervening (Studi Pada Pelanggan Sriwijaya Air Rute SemarangJakarta). Jurnal Ilmu Administrasi Bisnis, 6(1), 174-183.

Rauyruen, P., \& Miller, K. E. (2007). Relationship quality as a predictor of B2B customer loyalty. Journal of business research, 60(1), 21-31.https://doi.org/10.1016/j.jbusres.2005.11.006

Rotinsulu, E., Sumayku, S., \& Sambul, S. (2015). Pengaruh Harga, Produk Dan Promosi Terhadap Loyalitas Konsumen Big Jay Family Karaoke. Jurnal Administrasi Publik, 2(029).

Saeed, R., Nisar, F., Lodhi, R.N., Ahmad, M., Arshad, H.M. (2020). Impact of Sales Promotion on the Consumer Loyalty in the Telecommunication Industry in Pakistan. J. Basic Appl. Sci. Res. 3(5), 90-907. 
Salim, A. P., \& Hermani, A. (2018). Pengaruh Harga Dan Kualitas Produk Terhadap Loyalitas Pelanggan (Studi Pada Pelanggan Pasta Gigi Formula berusia> 15 tahun di Kelurahan Bulusan dan Tembalang, Kecamatan Tembalang, Semarang). Jurnal Ilmu Administrasi Bisnis, 7(2), 107-115.

Sari, I. P., Anindita, R., \& Setyowati, P. B. (2018). Pengaruh Bauran Pemasaran (Produk, Harga, Tempat dan Promosi) Terhadap Kepuasan Pelanggan Berubah Menjadi Loyalitas Pelanggan Pada Coldplay Juice Soji. HABITAT, 29(2), 57-64.

Sudari, S., Tarofder, A., Khatibi, A., \& Tham, J. (2019). Measuring the critical effect of marketing mix on customer loyalty through customer satisfaction in food and beverage products. Management Science Letters, 9(9), 13851396.

Turgunovna, M. S. (2021). The study of the history of the stone age in Uzbekistan and the application of modern technologies in archaeological research. International Journal of Social Sciences, 4(3), 335-340. https://doi.org/10.31295/ijss.v4n3.1762

Urun, S. (2019). Price, Promotion, Product Quality and Customer Loyalty. Karlstad Bus. Sch. J.

Usmanova, S., \& Mirkhamidova, M. (2021). Impacts of Islamic tourism on international peace and security: opportunities and threats. International Journal of Social Sciences, 4(3), 325-334. https://doi.org/10.31295/ijss.v4n3.1759

Wijaya, A. (2018). Pengaruh Kualitas Produk, Kualitas Layanan, Persepsi Harga, Dan Asosiasi Merek Terhadap Kepuasan Dan Loyalitas Pelanggan. Jurnal Bisnis Terapan, 2(01), 1-16.

Xie, Y. (2020). The relationship among marketing mix, customer satisfaction and customer loyalty of Chinese tourists to budget hotel of central Bangkok.

Zalova, Z., \& Karaduman, İ. (2018). The Effects Of Personalized Online Promotions On Consumer Loyalty: A Study İn Turkey. Internasional Journal Of. 